811.163.41'374

811.161.41'367:004.738.5

https://doi.org/10.18485/msc.2018.47.1.ch7

Јасмина Д. МОСКОВљЕВИЋ ПОПОВИЋ ${ }^{*}$

Оригинални научни рад

Универзитет у Београду

Филолошки факултет

Примљен: 20. 11. 2017.

Прихваћен: 27. 12. 2017.

\title{
ИНТУИЦИЈА ИЗВОРНОГ ГОВОРНИКА, ДЕСКРИПТИВНИ РЕЧНИЦИ И ГЛОБАЛНА РАЧУНАРСКА МРЕЖА КАО ИЗВОРИ ПОДАТАКА ЗА СИНТАКСИЧКИ ОПИС **
}

Рад је посвећен анализи различитих могућих извора језичке грађе, а посебно дескриптивним речницима и интернету као изворима података за синтаксички опис. У уводном делу рада изнете су опште информације о могућим изворима грађе, као и о променама у схватању шта представља адекватан корпус за анализу до којих је временом долазило. У наредним сегментима рада анализирани су интуиција изворног говорника, Речник МС и глобална рачунарска мрежа (интернет) као извори података за синтаксички опис. Све анализе засноване су на материјалу који је ексцерпиран из сваког разматраног извора, а односи се на један тип конструкција које су узете као огледне - конструкција с бенефактивним значењем у којима се јављају глаголи типа „даровати”. У завршном делу рада размотрен је значај информација садржаних у дескриптивним речницима и електронским базама података за опис синтаксичких карактеристика језика и истакнуте су предности које би пребацивање целокупног садржаја дескриптивних речника, а посебно Речника САНУ у дигитални формат имало не само за успешнији рад граматичара и лексикографа, већ и за очување и праћење даљег развоја лексичких ресурса српског језика.

Кључне речи: дескриптивни речници, Речник $M C-M X$, Речник $C A H У$, интернет; бенефактивне конструкције, глаголи типа „даровати”; српски језик.

\footnotetext{
*jasmina.moskovljevic@fil.bg.ac.rs

** Овај рад настао је у оквиру пројекта Стандардни српски језик: синтаксичка, семантичка и прагматичка истраживања (178004), који финансира Министарство просвете и науке Републике Србије. На 47. Међународном научном састанку слависта у Вукове дане, Београд, 14-18. IX 2017. изложен је под нешто другачијим насловом: Дескриптивни речници као извор података за успостављање лексичко-синтаксичких класа глагола. Захваљујем се свим учесницима конференције на изузетно корисној и подстицајној дискусији, која ме је и навела да донекле променим тежиште рада, а онда и његов наслов.
} 


\section{1. Увод}

Основни циљ граматике сваког језика јесте да на тачан, прецизан и теоријски доследан начин опише структурне, дистрибуционе и функционалне особености граматичких јединица и конструкција датог језика. У којој мери ће граматика конкретног језика одговорити на овај задатак свакако зависи и од тога каквим подацима располаже, односно којим и каквим језичким чињеницама аргументује своје постулате. Прикупљање грађе и формирање адекватног корпуса језичких чињеница које на прави начин репрезентују испитивани феномен увек је представљало први, нужан и незаобилазан корак у раду синтаксичара. Међутим, схватање о томе шта се подразумева под ,адекватним корпусом" и одговарајућим изворима грађе временом се мењало. До друге половине 20. века била су то махом дела лепе књижевности, посебно она укључена у тзв. „књижевни канон”, написана на стандардном језику (укључујући и народну књижевност и богату ризницу Вукових дела, кад је о нашем језику реч), затим дела књижевне критике, а понекад, али у знатно мањој мери, и научна дела и понеки текст из штампе. Најређи су били, ако их је уопште и било, примери који су потицали из разговорног језика. ${ }^{1}$ Граматике и језичке студије, како оне које су се бавиле српским језиком, тако и оне које су анализирале појаве у другим језицима, почивале су на грађи ексцерпираној из наведених извора.

У другој половини 20. века ситуација се променила. Док су, с једне стране, дескриптивне граматике и граматичари значајно проширили језичку основу на којој почивају њихови описи, укључивши као релевантне изворе и језик штампе, научне и стручне текстове из различитих области, као и корпус разговорног језика, дотле су, с друге стране, припадници генеративне теорије и сродних (а и несродних) формалних праваца, који су током последњих деценија прошлог и прве деценије овог века доживели свој пуни процват, умногоме сузили емпиријску основу на којој су почивала њихова језичка истраживања. Како сам Н. Чомски, тако и бројни други граматичари, у првом реду су се ослањали на сопствене интроспективне увиде и/или интуиције изворних говорника као на примарни извор података о томе шта јесте, а шта није добро граматички обликована, односно граматички исправна реченица у анализираном језику. Крајем 20., а посебно током првих деценија овог века, дошло је до великих и суштинских промена када је о могућим изворима језичке грађе реч. Убрзан прелазак на дигиталне форме текстова, а посебно настанак и ширење глобалне рачунарске мреже (интернета) учинили су језичке ресурсе широко доступним и буквално неограниченим. Све претпоставке и хипотезе о структурним ограничењима или домену употребе одређене конструкције данас је могуће проверити готово тренутно у корпусу текстова различитог порекла, жанрова и функција. Ипак, питање о предностима и недостацима различитих могућих извора података, па самим тим и о степену њихове упо-

${ }^{1}$ Изузетак представљају дијалектолошке студије које су се одувек заснивале на грађи из разговорног језика. 
требљивости и корисности за синтаксички (и сваки други) опис и даље остаје отворено.

Основни циљ овог рада јесте да упореди три могућа извора језичких података - интуицију изворног говорника, грађу из дескриптивног речника и грађу са интернета - и утврди колико и каквих информација које су значајне за синтаксички опис нуди сваки од њих. Као огледна конструкција, тј. као конструкција за коју су у сваком од извора тражени и упоређивани подаци, изабрана је конструкција с бенефактивним значењем коју формирају глаголи типа „даровати”. Три основна обележја овог типа конструкција су: 1. да се јавља у два различита структурна облика $-\mathrm{V}+\mathrm{NP}_{1 \text { dat }}+\mathrm{NP}_{2 \text { асс }}$ (Иван је даровао Ани къигу) алтернира са $\mathrm{V}+\mathrm{NP}_{1 \text { асс }}+\mathrm{NP}_{\text {2ins }}$ (Иван је даровао Ану къигом); 2. да је број глагола са којима се ове конструкције формирају врло ограничен; 3. да је реч о тровалентним дитранзитивним глаголима чији су аргументи носиоци семантичких улога бенефактор, бенефицијент и тема. ${ }^{2}$

\section{2. Интуиција изворног говорника као извор података за синтаксички опис}

Иницијалне податке о конструкцијама с бенефактивним значењем у којима је могуће ротирати директни и индиректни објекат уз истовремену промену падежних обележја одговарајућих именичких фраза налазимо у Московљевић Поповић (2000: 300, 2007: 75-76). У оквиру ширег поглавља у коме је дат преглед синтаксички и семантички разнородних класа глагола уз које су могући различити видови алтернације допуна, наводе се и глаголи $\partial a-$ ровати, нудити, понудити, служити, послужсти и исплатити ${ }^{3}$ као глаголи уз које конструкција с бенефактивним значењем $\mathrm{V}+\mathrm{NP}_{1 d a t}+\mathrm{NP}_{2 a c c}$ алтернира са конструкцијом $\mathrm{V}+\mathrm{NP}_{\text {lacc }}+\mathrm{NP}_{\text {2ins }}$. Такође се наводи и да овај тип инверзије допуна није нужно прихватљив, односно граматичан уз све глаголе блиског значења и то илуструје следећим примером: Бошко је поклонио Марку књигу vs. "Бошко је поклонио Марка књигом (ibid., 76). Сама појава, њена карактеризација, као и примери којима се илуструје, издвојени су и описани на основу језичке компетенције аутора, изворног говорника српског језика. Није изложена ни анализирана никаква додатна грађа.

Разматрајући методолошку валидност интуиције и судова о граматичности исказа изворног говорника као примарног извора података за формулисање и аргументовање синтаксичких генерализација, Васов и Арнолд (2005:1481) истичу да се стандарди прикупљања података који се у суседним

2 За детаљну анализу овог типа конструкција в. Московљевић 2018. Такође в. и Ружић 2005: 525-526, Зовко Динковић 2007, као и рад М. Ковачевића у овом Зборнику.

${ }^{3}$ Глагол исплатити овде је, очигледно, наведен грешком - између реченица Исплатила му је новач (за ауторска права) и Исплатила га је новцем (од ауторских права) не успоставља се исти значењски однос као између реченица Понудила му је кафу и ратлук и Понудила га је кафом и ратлуком. Овакве грешке нису ретке и очекиване су када је једини извор података знање/интуиција изворног говорника. 
дисциплинама подразумевају, у лингвистици често заобилазе, као и да их бројни лингвисти уопште не узимају у обзир. Ово се посебно односи на лингвисте који припадају школи генеративне граматике, у чијим радовима интуиција изворног говорника језика има (прећутно јој додељен) привилегован статус. Васов и Арнолд сматрају да је директна последица оваквог приступа подацима стварање „елаборираних теоријских конструката који почивају на узнемиравајуће климавим емпиријским доказима" (ibid.: 1482). Уз то, они скрећу пажњу и да се судови о граматичности два изворна говорника могу у великој мери разликовати - оно што је за једног говорника добро обликован и граматичан, за другог може бити потпуно неграматичан и неприхватљив, или само маргинално прихватљив исказ. Чак се и судови једног истог говорника могу, у зависности од језичког, али и ванјезичког контекста, мењати од прилике до прилике (Шуц 2016). С друге стране, неспорно је да језичко знање и интроспективни судови изворног говорника могу да пруже валидне иницијалне податке о уоченом језичком феномену, као и да омогуће формулисање хипотеза које је даље (на основу прикупљене грађе и чињеница) могуће проверити и онда их или прихватити, или одбацити.

Овакви ставови о вредности језичког знања и интуиције изворног говорника потврђени су и у овом испитивању - постојање бенефактивних конструкција с глаголима типа „даровати” у којима је могућа ротација/инверзија допуна идентификовано је и иницијално окарактерисано на основу интроспективних увида и језичког знања изворног говорника. На исти начин утврђен је и обим глаголске класе уз чије чланове је овај вид алтернације предикатских допуна могућ - у свом првобитном облику ова класа имала је (само) пет чланова: даровати, нудити, понудити, служсти и послужити.

\section{3. Дескриптивни речници као извор података за синтаксички опис}

У наредном кораку анализе ексцерпирана је грађа из шестотомног Речника српскохрватскога књижевног језика Матице српске (РМС). Претраживано је дигитализовано издање Речника, простом претрагом, за сваки глагол појединачно и за сваки том Речника посебно. Речник МС сврстава се у речнике средњег обима (садржи нешто више од 150.000 речи) и заснива се на грађи из око 700 извора: књижевних и научних дела, превода, уџбеника, часописа, годишта дневних и недељних листова. ${ }^{4}$ Грађа обухвата временски период од друге половине 19. до друге половине 20. века (тачније, до 1966. године). Како је реч о једнојезичном дескриптивном речнику намењеном првенствено изворним говорницима српског језика, синтаксичке информације у њему су штуре. Тако је, на пример, податак о глаголској рекцији бележен само „ако значење глагола зависи од његове рекције” када се ,рекција обично означава-

${ }^{4}$ Речник српскохрватскога књижевног језика, књ. 1: 9. 
ла скраћеницом прел., непрел. или стављањем предлога и објекта у заграду ...” (РМС 1: 13). Иако овај, као ни други дескриптивни речници, не садржи експлицитно изречену информацију о рекцијским и другим синтаксичким својствима лексема, он представља богат извор података о разноликости забележених речи. Уз то, примери који се наводе уз одреднице не представљају само илустрацију одговарајућег значења дате лексеме, већ сведоче и о њеној дистрибуцији, односно о структурним својствима конструкција у које се дата лексема укључује.

То се потврдило и приликом ексцерпције језичке грађе која се тиче оног типа конструкција који је значајан за анализу и поређење у овом раду. Од почетне листе на којој се налазило само неколико (пет) глагола, дошло се до готово петоструко дужег списка од четрнаест глагола уз које је могућа алтернација допуна у конструкцијама са бенефактивним значењем: даровати, даривати, дарити, надарити, подарити, подаровати; нудити, понудити, нуткати, нуђати, занудити; служити, послужити и послужсивати. Иако је махом реч о лексемама које су деривационо сродне са лексемама са првобитне листе, њихово укључивање у анализу пружило је додатне потврде не само о обиму, већ и о продуктивности глаголске класе „даровати”. Неки од глагола са новоформиране листе (дарити, подаровати, нуђати и занудити) нису ми као аутору првобитне листе ни били познати, па не би ни могли да буду укључени на листу да није извршена претрага садржаја речника. Уз значајно проширење обима листе, примери наведени уз поједине лексеме (а претраживан је укупан садржај речника, а не само садржај глаголских одредница циљне групе глагола) пружили су чврсте потврде о реченичним структурама у оквиру којих се лексеме које припадају датој глаголској класи реализују. Тако је, између осталог, потврђено и да се највећи број (девет од четрнаест) издвојених глагола реализује у обе алтернативне структуре - у конструкцији $\mathrm{V}+\mathrm{NP}_{1 \text { acc }}+\mathrm{NP}_{2 \text { ins }}$, као и у конструкцији $\mathrm{V}+\mathrm{NP}_{1 \text { dat }}+\mathrm{NP}_{2 a c c} \cdot{ }^{5}$

1. Брак је био дарован многом децом.(МС3)// Дарова сваком брату убрус и чарапе. (MC1); 2. Дарива [наконче] кошуљииом, па га предаде матери. (MC1)// Загорка ... видовитост посинку дарива. (МС2); 3. Земља га [храст] са трулежом дари. (МС1); 4. [Знао је Мустафа] да ће га султан, буде ли од Руса поражен ... надарити свиленим конопием. (MC5); 5. Трипут сам те подарио својим милосрђем. (МС4)// Професор му [је] подарио двије сребрне двосексерке. (MC1); 6. Боже ... подаруј ме добрим здрављем ... подаруј ми свако добро. (МС4); 7. Нуди своје пријатеље мочом. (МС3)// Лијечник [га је] озбиљьо ... мотрио и нудио му капљице. (МС2); 8. Необично [му је] ласкало кад су га понудили кандидатуром за саборског заступника.(МС4)// Сестра му понуди лимунаду. (МС4); 9. Нутка га воћем или закуском. (МС2); 10. Нућа варошанина и вином. (МС3)// Поновно му [је] нуђала крух. (МС3); 11. И зануди га [дијете] својим млијеком.(МС2); 12. Почеше служити чајем са прженим ... крухом. (МС3)// Сеоске девојке у кломпама служиле су нам ракове.(МС2); 13. Када су се јелом подмирили, Милош их је вином послужио.(МС4)// A мрку му каву послужсила, иза каве бистрииу ракију. (MC1); 14. Примати »визите«, 무луживати их кафом... (МC1).

${ }^{5}$ Наведен је само по један пример за сваки глагол у свакој од конструкција. Број примера забележених у Речнику је у већини случајева био много већи: даровати (25), даривати (31), дарити (1), надарити (8), подарити (6), подаровати (2); нудити (21), понудити (30), нуткати (3), нуђати (4), занудити (2); служити (4), послужити (8) и послуживати (2). 
Грађа ексцерпирана из речника омогућила је и формулисање генерализација које се односе на семантичка обележја чији су носиоци аргументи предиката (бенефактор, бенефицијент и тема), као и генерализација које се односе на формална својства анализираних конструкција, као што су оне које се тичу могућности неизрицања (нереализације) неког од аргумената, могућност пасивизације и сл. ${ }^{6}$ Уз то, анализа примера показала је да блиске морфолошке, као ни блиске значењске везе између појединих глагола не значе да ће се глагол нужно наћи у класи „даровати”, односно у класи глагола бенефактивног значења уз коју је могућа ротација допуна - глагол „обдарити" је и деривационо и значењски близак са првих пет глагола са листе, али је његова реализација могућа само у конструкцији $\mathrm{V}+\mathrm{NP}_{1 a c c}+\mathrm{NP}_{2 \text { inn: }}$ Бог га је ... обдарио здрављем. (МС4)// Обдари ме ... тијем даром ... (МС5), док су искази: "Бог ми је обдарио здравље и "Обдари ми тај дар неграматични. Такође, ни на основу глаголског вида дате лексеме не може се предвидети да ли је њена синтаксичка реализација могућа у обе или само у једној (и којој) алтернирајућој структури (в. примере 1-14).

Када је о односима класе глагола типа „даровати” према другим класама глагола реч, претрага садржаја лексичких одредница у Речнику $M C$ у којима се значење лексеме често одређује преко синонимних лексема ${ }^{7}$ (са којима циљна лексема може, али и не мора да дели валентна и рекцијска својства) омогућила је да се недвосмислено потврди да се глаголска класа „даровати” налази на својеврсном пресеку између две сродне глаголске класе са којима деле нека синтаксичка и семантичка обележја и са којима формира лексичко-валентни континуум. На једном крају тог континуума налазе се дитранзитивни глаголи типа „частити”, који се реализују искључиво у оквиру обрасца $\mathrm{V}+\mathrm{NP} 1_{\text {acc }}+\mathrm{NP} 2_{\text {ins }}$, док су на другом крају они глаголи који се реализују искључиво по обрасцу NP $1_{\text {dat }}+\mathrm{NP} 2_{\text {acc }}$. У исту класу као „частити” сврставају се, нпр., и глаголи: обдарити, гостити, погостити, дворити, наградити, почастити, поткупити, хранити, нахранити, накљукати, опити, напити, снабдети, полити, залити и сл., док су у другој групи глаголи: поклонити, купити, предати, пружсти, дати, додати, уручити, наручити, набавити, направити, иштрикати, сашити, послати, рећи, причати, показати, представити, предавати, читати, писати, иртати и сл. ${ }^{8}$

Укупно узевши, изузетно богата и временски и територијално разуђена грађа добијена претрагом дескриптивног једнојезичног речника, Речника $M C$, омогућила је не само значајно проширење обима глаголске класе „даровати", већ је из ње било могуће излучити и читав низ релевантних језичких чињеница које су послужиле као стабилна, емпиријски заснована основа за закључивање о различитим формалним и семантичким обележјима бенефактивних конструкција са глаголима типа „даровати”. С друге стране, у речнич-

\footnotetext{
${ }^{6}$ За детаљнију анализу како формалних, тако и семантичких својстава ових конструкција в. Московљевић Поповић (2018).

${ }^{7}$ О овом стандардном лексикографском поступку в. у Аткинс и Рандел 2008. и Апресјан 2000

8 За више, в. Московљевић Поповић (ibid.).
} 
кој грађи нису за све глаголе пронађени примери који би потврдили њихову употребу у оба типа конструкција.

\section{4. Интернет као извор података за синтаксички опис}

У последњем сегменту истраживања извршено је претраживање глобалне рачунарске мреже, интернета, како би се проверило могу ли се пронаћи и потврдити недостајући подаци. Интернет се и може и не може посматрати као корпус - са једне стране он свакако не испуњава услове које мора да задовољи пуновредни електронски корпус једног језика на начин на који је то дефинисано у рачунарској и корпусној лингвистици, ${ }^{9}$ али гледано из другог угла он то донекле и јесте: готово целокупна дневна штампа, бројна књижевна дела различитих жанрова, научни списи и разне друге врсте текстова доступни су на интернету, а ту су и најразличитији форуми и блогови са мноштвом језичког материјала, укључујући и онај који по форми и садржини више одговара узусима разговорног него писаног језика. Све то чини га неисцрпним извором сваколиких, па и језичких података. Врло често нестандардна и нестандардизована по форми и садржају, али врло актуелна језичка грађа доступна на интернету може да садржи податке од значаја за различите нивое и облике лингвистичке анализе које није могуће наћи у другим изворима.

Претрагом укупног садржаја Речника MC нису пронађене адекватне потврде за пет глагола: дарити, надарити, нуткати, занудити и послуживати. За свих пет глагола примери су недостајали за само једну од алтернирајућих конструкција $-\mathrm{V}+\mathrm{NP}_{1 \text { dat }}+\mathrm{NP}_{2 a c c}$ (која је иначе у језику много чешћа од конструкције са допунама у акузативу и инструменталу, али је у грађи из Речника ипак није било). Провера на интернету обезбедила је недостајуће примере и са овим глаголима:

15. А дари му на трапези паче сувог злата. (ПС - www.rastko.rs); 16. Мајка природа нам то надарила, рецимо судбина итд. (www.haoss.org)// ... нека искористи све предности које јој ㄹ природа надарила...(www.forum.hr)//Уколико вам природа није надарила идеалан метаболизам и атлетску фигуру, за постизање оптималне телесне тежине се морате nотрудити сами.(www.b92.net)// Надари срећу сестрама, мени и намој мами. (www.most. ba); 17. С времена на време сам му нуткала „Аптамил”. (www.roditeljportal.com)// „Ајде попи једну, ваљь се", нуткала му ракију. (www.ukat.org.rs)// Jутрос сам joj свашта нешто нуткала и на крају ништа није узела.(www.ringeraja.rs)// Партија са највише коалиционе потениије редовно се(бе) нутка(ла) двојичи повећих и посве различитих партнера...(www. danas.rs); 18. Да им домаћин зануди плату, они би се ... (AJ); 19. Док нас је она послуживала чајем, Влад је испратио једног који је управо завриио боравак. (glaszapadnesrbije. rs)// Гостима ⿺е често послуживао ухолаже, змије и пите од меса носорога.(https://www. express.hr)// Кухала сам топле напитке и послуживала их факултетском особљу. (https:// issuu.com)//... који ће јој певати песму из „Мале сирене” док јој буде послуживао храну. (mondo.rs)

${ }^{9} \mathrm{O}$ правилима формирања и карактеристикама које мора да задовољи електронски корпус једног језика в., нпр., О’Киф/ Макарти 2010. 
За два глагола, дарити и занудити, који су и Речнику $M C$ обележени као специфични, ${ }^{10}$ пронађен је само по један пример са конструкцијом $\mathrm{V}+\mathrm{NP}_{1 \text { dat }}$ $+\mathrm{NP}_{2 a c c}$, и то у изворима с почетка 19. и 20. века, што наводи на закључак да је реч о архаизмима. За преостала три глагола (надарити, нуткати и послуживати) пронађен је далеко већи број примера, и то из савременог језика (овде су наведени само неки), што указује да је реч о лексичким јединицама које су део активног, продуктивног вокабулара.

Уз то, претрага на интернету довела је и до проширења листе глагола који се реализују у конструкцијама с бенефактивним значењем у којима је могућа ротација допуна - листа је проширена укључивањем још једног члана - глагола „донирати”. Овај глагол је у скорије време постао део вокабулара српског језика и нема га ни у шестотомном, ни у једнотомном речнику Матице српске. У грађи са интернета потврђена је његова употреба у конструкцији $\mathrm{V}+\mathrm{NP}_{1 \text { acc }}+\mathrm{NP}_{2 \text { ins }}$ (в. 20.), као и у конструкцији $\mathrm{V}+\mathrm{NP}_{1 \text { dat }}+\mathrm{NP}_{2 a c c}$ (в. 21):

20. Олимпијски комитет нас је донирао опремом за медицинска испитивања. (www. rzsport.gov.rs)//... донирао је опремом и играчкама новоотворени дјечји вртић у Ловасу. (www.skyscrapercity.com)// Ученици су симболично донирали удругу псећом храном и посластицама. (www.os-ntesla-ri.skole.hr)// ... преко којих су ротаријанци опремом и новцем донирали сочијално угрожене... (https://issuu.com/rotary_magazin)// И из болнице и из дечјег дома стигле су осуде ..., уз подсећане да се установе донирају и новием, али углавном храном и другом робом. (www.rts.rs)

21. Дванаест привредних субјеката из Лесковиа и Власотиниа донираће Опитој болници Лесковач око пет милиона динара. (www.tvl.rs)//Легендарни кошаркашки тренер сав приход од свог опрочтајног меча ... донираће Дечјој клиници у Тириовој. (www.blic. rs)// Запослени у МШ „Живорад Грбић” и синдикат запослених ... донирали су новаи Центру за вантелесну оплодњу. (www.kolubarske.rs)// Наши војници донирали пакете с храном дјечјем дому у Кенији. (https://www.24sata.hr)// Активисти омладинске организације ВИФО донирали ,Колевки” играчке, одећу, обућу и књиге... (https://www.subotica.com)//... четири војвођанска предузећа ће установама или локалним самоуправама у покрајини донирати робу вредну укупно око 150.000 евра... (http://rtv.rs)

Ово проширење глаголске класе за један члан не би само по себи било од великог значаја да не указује на другу важну чињеницу. Наиме, укључивање глагола „донирати”, који је у језику нов, међу глаголе типа „даровати” сведочи да је тип синтаксичке алтернације у коме конструкција с бенефактивним значењем $\mathrm{V}+\mathrm{NP}_{\text {lacc }}+\mathrm{NP}_{2 \text { ins }}$ алтернира са конструкцијом $\mathrm{V}+\mathrm{NP}_{1 \text { dat }}+$ $\mathrm{NP}_{2 a c c}$ присутан и продуктиван и у савременом језику.

\section{5. Закључне напомене}

Поређење језичког знања изворног говорника, садржаја дескриптивног речника и садржаја интернета као извора података за синтаксички опис показало је (као што се и могло очекивати) да сваки од испитаних извора има

${ }^{10}$ Уз први стоји ознака која указује да се јавља само у песничком језику, а уз други су наведена укупно два примера: један из дела Ива Ћипика, а други из језика Ивана Горана Ковачића. 
одређене предности и недостатке. Интроспективне опсервације и језичка интуиција изворног говорника лако су доступне, али и недовољно поуздане и подложне најразличитијим утицајима - отуда је њихова улога најзначајнија у иницијалној фази уочавања и омеђавања језичког феномена који је предмет анализе. Грађа прикупљена претрагом интернета показала се драгоценом када је требало пронаћи недостајуће податке, као и податке који се односе на појаве које су у језику нове. Захваљујући свакодневном и огромном приливу текстова најразличитијег порекла, интернет је неисцрпни извор грађе, посебно кад је о језичким иновацијама и променама реч. Међутим, како је реч о „сировим” чињеницама које ни на који начин нису организоване и систематизоване, грађа са интернета корисна је само онда када се тачно зна шта се тражи, у фази провере и допуне података.

Као најзначајнији извор грађе за опис конструкција које су у овом раду употребљене као ,јединица поређења" показао се шестотомни дескриптивни једнојезични Речник српскохрватскога књижевног језика Матице српске. Језичка грађа ексцерпирана претрагом његовог укупног садржаја показала се и довољно обухватном и довољно поузданом да омогући прецизно дефинисање и опис циљног типа конструкција - конструкција с бенефактивним значењем у којима се јављају глаголи типа „даровати” и у којима је могућа инверзија допуна. При томе треба имати у виду да се Речник Матице српске сврстава међу речнике средњег обима и да је претрага његовог дигитализованог садржаја вршена на најједноставнији начин, без употребе било каквих софтверских алатки које би је учиниле бржом и ефикаснијом. Чак и на тај начин добијено је обиље релевантних и разноврсних језичких чињеница.

Може се само претпоставити шта би све од грађе и језичких података постало доступно кад би била могућа потпуно аутоматизована претрага дескриптивних речника као што су Речник MC или Речник српскохрватског књижевног и народног језика САНУ. Пребацивање садржаја ова два речника у одговарајући дигитални формат, односно у рачунарски читљив текст (хипертекст), као и креирање одговарајућих оруђа (софтвера) за њихову брзу и ефикасну претрагу омогућило би приступ готово неограниченим изворима језичких података, што би, последично, отворило пут и за далеко прецизнији и систематичнији опис језичких феномена на различитим нивоима лингвистичке анализе, укључујући и синтаксички. Такође, сама природа хипертекста је таква да омогућава његову сталну, релативно једноставну измену и допуну. То у ствари значи да би садржај дескриптивних речника у одговарајућем електронском формату могао да се без посебних додатних улагања увек изнова иновира, допуњује и обогаћује - систематизовани подаци о општим и специфичним морфолошким, морфосинтаксичким, синтаксичким, семантичким и прагматским својствима појединих лексема и класа лексема могли би се преузимати директно из студија које су засноване управо на анализи грађе преузете из текстова у речнику. Успостављање овакве двосмерне везе унутар система речник-систем језичког описа обезбедило би да садржај обе његове компоненте увек буде актуелан, савремен и у највећој мери прилагођен потребама корисника. Тако би дескриптивни речници у електронском 
формату могли да у потпуности одговоре основној сврси једнојезичних речника - очувању и неговању лексичког блага језика, а тиме и очувању и неговању идентитета народа који тим језиком говори.

\section{ИЗВОРИ}

МС - Речник српскохрватскога књижевног језика, књ. 1-3, Нови Сад-Загреб: Матица српска-Матица хрватска, књ. 4-6, Нови Сад: Матица српска, 1967.

AJ - Андрија Јовићевић, Ријечка нахија у Црној Гори, Српски етнографски зборник, књ. XV, Београд, 1911.

ПС -Павле Соларић, Гозба. Сабране пјесме, Београд: АМИ, 1999. [www.rastko.rs]

Електронскиизвори: www.blic.rs, www.rts.rs, www.most.ba, www.forum.hr, www. b92.net, www.haoss.org, www.roditeljportal.com, http://rtv.rs, www.24sata. $\mathrm{hr}$, www.ukat.org.rs, www.ringeraja.rs, www.danas.rs, glaszapadnesrbije.rs, www.express.hr, www.politika.rs, www.os-ntesla-ri.skole.hr, https://issuu. com, https://issuu.com/rotary_magazin, www.rzsport.gov.rs, www.subotica. com, www.skyscrapercity.com, www.mondo.rs, www.kolubarske.rs,

\section{ЛИТЕРАТУРА}

Апресјан 2000: Juri Apresjan, Systematic Lexicography, New York: Oxford University Press.

Аткинс/ Рандел 2008: В. T. Sue Atkins и Michael Rundell, The Oxford Guide to Practical Lexicography, New York: Oxford University Press.

Васов/Арнолд: Thomas Wasow и Jennifer Arnold, Intuitions in linguistic argumentation, Lingua 115, 1481-1496.

Ковачевић 2018: Милош Ковачевић, Интердепенденција пермутабилних форми правог и неправог објекта у синтагмама с глаголом нудити, у овом Зборнику.

Зовко Динковић 2007: Irena Zovko Dinković, Dative Alternation in Croatian, Suvremena lingvistika, 63, 65-83.

Московљевић 2000: Јасмина Московљевић, Супкатегоризаиија глагола у савременој лингвистичкој теорији (докторска дисертација, Филолошки факултет, Универзитет у Београду).

Московљевић Поповић 2007: Jasmina Moskovljević Popović, Ogledi o glagolskoj potkategorizaciji, Beograd: Čigoja.

Московљевић Поповић 2018: Јасмина Московљевић Поповић, О бенефактивним конструкцијама са глаголима типа даровати, Српски језик XXIII, 99-115.

О'Киф/Макарти 2010: Anne O'Keeffe и Michael McCarthy (yp.), The Routledge Handbook of Corpus Linguistics, Abingdon: Routledge. 
Ружић 2005: Владислава Ружић, Проста реченица као синтаксичка целина, у: П. Пипер, И. Антонић, В. Ружић, С. Танасић, Љ. Поповић, Б. Тошовић, Синтакса савременог српског језика. Проста реченица, ред. Милка Ивић, Београд: Институт за српски језик САНУ, Београдска књига - Нови Сад: Матица српска.

Шуще 2016: Carson T. Schütze, The empirical base of linguistics - Grammaticality judgments and linguistic methodology, Berlin: Language Science Press.

Jasmina D. Moskovljević Popović

\section{NATIVE SPEAKERS' INTUITIONS, DESCRIPTIVE DICTIONARIES AND INTERNET AS DATA SOURCES FOR SYNTACTIC DESCRIPTION}

Summary

The main aim of this paper is to review and compare native speakers' judgments of the grammaticality/acceptability of sentences, the content of descriptive dictionaries, and the World Wide Web (Internet) content as data sources for syntactic descriptions and generalizations. Apart from presenting the framework of the study, in the introductory part of the paper (sections 1 and 2) introspective intuitions about well-formedness of utterances as primary data source in grammar constructing have been discussed. In the central part of the study (sections 3-4), the descriptive dictionary of Serbian language (The MS dictionary), and the World Wide Web as data sources have been reviewed and compared. Evidence available in each data source about the particular type of the construction (the benefactive construction with ditransitive verbs of the type 'darovati' - 'to give as a gift') had been excerpted and used for the purpose of comparison. In the final part of the paper (section 5), conclusions are drawn about the comparative findings, and the relevance of digitization of the existing descriptive paper dictionaries of the Serbian language, particularly of the SANU dictionary, is discussed.

Key words: native speakers' judgments, descriptive dictionaries, the MS dictionary, the SANU dictionary, Internet, benefactive constructions, verb class 'darovati' ('to give as a gift'), Serbian language. 